Турк С.Н., Дорогокупля И.И., Дрожжин И.В.

\title{
Внешняя политика Египта на современном этапе
}

Кубанский государственньй аграрный университет имени И.Т. Трубилина

doi: $10.18411 / \mathrm{j}-08-2020-95$

(Россия, Краснодар)

idsp: ljournal-08-2020-95

\section{Аннотация}

В данной статье рассматриваются внешняя политика, торгово-экономические отношения, история войн, споров и конфликтов Арабской Республики Египет с другими государствами мира, начиная с середины XX века и заканчивая сегодняшними днями.

Ключевые слова: Египет, политика, экономика, конфликты, споры, войны, сотрудничество, взаимоотношения, организации, терроризм, США, СССР, Россия, Израиль

\section{Abstract}

This article discusses foreign policy, trade and economic relations, the history of wars, disputes and conflicts of the Arab Republic of Egypt with other countries of the world, starting from the middle of the 20th century and ending today.

Key words: Egypt, politics, economy, conflicts, disputes, wars, cooperation, relations, organizations, terrorism, USA, USSR, Russia, Israel

Географическое положение Египта в большей степени посодействовало формированию внешней политики в этом государстве. Египет находится между Африкой и Азией, на берегу Красного моря, что обеспечивает проход через Суэцкий канал из Средиземного моря в Индийский океан. Из чего следует, Египту необходимо быть сильным государством, поскольку подвержен нападкам других стран.

Отношения с соседними государствами завязывались на почве контроля Нила, поскольку от водных ресурсов зависит существование Египта. Важными соседями являются арабские страны, и правители традиционно старались поддерживать отношения с ними. При этом, до сих пор отношения с Израилем остаются натянутыми, расположенным на востоке от границ страны.

Стоит отметить, что расположение Египта сделало страну интересной для сверхдержав, в связи с чем Абдель Насер - президент Египта (23 июня 1956 - 28 сентября 1970 г.г.) смог получать экономическую и военную помощь от некоторых стран. В 50-60-е годы XX века Египет превратился в ведущую державу арабского мира, он оказывал сильное политическое и идеологическое воздействие на события, происходившие в регионе, был в состоянии существенно влиять на ход многих событий на Ближнем Востоке и в Африке[3].

Важно обратить внимание на арабо-израильский конфликт, поскольку Египет при Хосни Мубараке (14 октября 1981 - 11 февраля 2011 г.г.) участвовал как борец с радикальным исламизмом. Это помогло получать экономическую помощь от стран Запада и Арабского мира. Начало переговоров на основе принципа «земля в обмен на мир» стало возможным не только в результате ослабления экстремистского крыла ООП, но и благодаря укреплению позиций сторонников «миротворческой» стратегии внутри правящих кругов Израиля[4].

Изучая внешнюю политику Египта, нельзя не обратить внимание на население страны. Оно является арабо-исламским, при этом у страны есть свои диалекты, обычаи, история. Являясь главной частью арабского мира, политическими соперниками Египта были Ирак и Саудовская Аравия, а союзником Сирия. Но после 1970-х годов, из-за подписания мирного договора с Израилем, президент Египта Анвар Садат, Сирия стала 
главным соперником Египта. С другими арабскими соседями Египет находится в хороших отношениях. Например, с западным соседом - Ливией, а также с южным Суданом, несмотря на спор по поводу треугольника Халаиба, который не может разрешиться по сей день. Эта территория богата нефтью, вместе с тем, имеет выход к Красному морю. Изначально, эта территория принадлежала Египту, но в 1899 году. Соединенное Королевство подписало договор о совместном управлении этой территории как Егпита, так и Судана. С тех времен, эти страны не могут поделить треугольных кусок земли в пустны Сахара.

Отдельно хочется отметить отношения Египта с Соединенными Штатами. Эти страны установили дипломатические отношения в 1922 году после обретения Египтом независимости от Великобритании. Их отношения строятся на торговых отношениях, борьбе с терроризмом, США поддержали в 2011 году переход Египта к демократии. Одним из главных аспектов построения межгосударственных отношений является военное сотрудничество. После мирного договора с Израилем, Египет получил помощь в размере 19 миллиардов долларов в период с 1979 по 2003 года. Эта сумма по величине является второй после военной помощи США Израилю. А в 2009 году США предоставил военную помощь в размере 1,3 миллиарда долларов. Во время правления Клинтона, Египет значился как более значимое государство в арабском мире и ключевым союзником США на Ближнем Востоке. США обеспечивал поддержание постоянной безопасности Суэцкого канала, который является частью международного пути для американских военных кораблей. Египет является самой сильной военной державой на африканском континенте, а также в соответствии с Яффой, центром стратегических исследований ежегодного ближневосточного стратегического баланс, второй по величине на Ближнем Востоке, после Израиля. Но в последнее время отношения между США и Египтом стали значительно более напряженными. Все связано с тем, что Египет не хочет отправлять войска в Афганистан и Ирак. Египет отказался в 2003 году поддерживать оккупацию Ирака после войны и отказался выполнить просьбы США об отправки в страну даже под эгидой ООН. При всем этом Египет поддержал Штаты в борьбе с международным терроризмом после произошедшего в стране. 11 сентября смертники «Аль-Каиды» угоняют американские самолеты и направляют их в башни Всемирного торгового центра в Нью-Йорке и здание Пентагона в Вашингтоне. В результате этих терактов погибли 3000 человек [1]. Когда США сделали сокращение военной помощи Египту после свержения с Мурси и подавления движения Братьев - мусульман, он продолжил финансирование операций по борьбе с терроризмом, пограничной безопасности и безопасности на Синайском полуострове и в секторе Газа, считается очень важным для безопасности Израиля. Президент Сиси (с 8 июня 2014 года) заявил, что Египет будет проводить независимую внешнюю политику, направленную на обеспечение безопасности в Арабском мире «так, как ее видит Египет». Сиси попытался принять более сбалансированную внешнюю политику, не разрывая отношения с США, наладить отношения с Россией, Францией и арабскими странами Персидского залива - группой Совет сотрудничества арабских государств Персидского залива. Диверсификация поставок оружия для него является способом освободиться от полного подчинения Соединенным Штатам. В итоге администрация Обамы после выражения недовольства признала военный переворот в Египте как уже совершившийся факт, и после этих событий пересмотрела свою помощь Египту. При этом, Египетские власти регулярно не устраивали действия Обамы, но при всем при этом, военное сотрудничество этих стран было продолжено. Весной 2015 года в Египте было совершено несколько террористический актов, и в связи с этим некоторые конгрессмены просили администрацию Обамы отменить штрафные меры против Египта и продолжить поставлять вооружения в прежнем объеме. После инаугурации Дональда Трампа 20 января 2017 года были предприняты меры по изменению отношений с Египтом, 
который сложились во временя правления Барака Обамы, политика которого привела к ухудшению отношений с практически всеми странами Ближнего Востока.

Отношения Египта и ЕС строятся на основе торгового партнерства и в настоящее время большой процент импорта и экспорта Египта направлены на Европейский союз. Основными статьями импорта из ЕС были химические вещества, транспортное оборудование, автомобильные генераторы, продукты питание и сельскохозяйственная продукция. Египет входит в Европейскую политику соседства для более тесного сотрудничества с странами ЕС. Через некоторое время после начала арабской весны в марте 2011 года ЕС принял совместное заявление «партнерство для демократии и разделил процветание с южным Средиземноморьем», был настроен на создание общественной поддержки, финансовую поддержку для продвижения процесса демократизации. Эта декларация предположила дальнейшее углубление предыдущего Соглашения о свободной торговле, предусмотренного в 2004 году, приспособленного к включению областей, таких как торговля услугами, государственные закупки, соревнование, права на интеллектуальную собственность и защита инвестиций. После египетского кризиса (2011-2014 г.г.), ЕС обсудили возможность пересмотра предоставления помощи Египту. Дело в том, что вооружения могли использоваться для репрессий, и в итоге не сумели останавливать программу помощи, которая могла навредить гражданскому населению. Ранее, в июле 2013 года, Верховный представитель Европейского союза по иностранным делам и политике безопасности Кэтрин Эштон посетила Египет для урегулирования конфликта. Через год после посещения, представитель поднял проблему смертной казни и судебных исков в отношении к журналистам и активистам. Верховный представитель Европейского союза по иностранным делам и политике безопасности. В XXI веке ЕС воспринимается не только как крупное интеграционное экономическое образование, но и как самостоятельный участник военно-политических, экономических, социальных и гуманитарных процессов, происходящих в мире[5].

Дипломатические отношения Египта и СССР начались 26 августа 1943 года и изначально, еще в 16 веке, дружба Египта и России завязывалась на поддержке христиан в арабской стране. В 1950 году, антиимпериалистическая политика Гамаль Абдель Насера принесла ему поддержку со стороны СССР, после чего, в 1964 году его наградили звездой Героя Советского Союза с вручением ордена Ленина. Но отношения были испорчена после смерти Насера, когда новый глава Египта Анвар Садат начал движения в сторону Запада. Но несмотря на это, между Москвой и Каиром был подписан договор о дружбе и сотрудничестве.

Однако в 1976 году Египет при Анваре Садате в одностороннем порядке признал недействительным этот договор. Наступил период свертывания советскоегипетских политических контактов, хотя СССР продолжал выполнять свои обязательства по заключенным соглашениям и контрактам. Развитие возникло в средине 1980-х годов вследствие индивидуальной роли экс-президента Египта Хосни Мубарака. За минувшие года русско-египетская связь существенно укрепилась, выйдя на качественно свежий уровень. Среди двух государств исполняется интенсивный общественно-политический диалог.Отношения были восстановлены при Хосни Мубараке в 1984 году. В апреле 2001 года Мубарак посетил Москву, в ходе чего была подписана программа развития экономического, промышленного, научно-технического сотрудничества, которая была расчитана на 10 лет. Помимо этого, была подписана Декларация о принципах дружественных отношений и сотрудничества. Отношения улучшились после падения коммунизма в СССР и появления России в качестве независимого политического игрока.

Товарооборот между обеими странами уже составляет около полумиллиарда долларов в год и имеет тенденцию к росту. К числу новых, наиболее перспективных областей сотрудничества относится сфера коммуникации и информационных технологий[2]. В апреле 2008 года страны согласились работать над Египетской 
ядерной программой, которая была необходима для гражданских целей. После свержения президента Египта Мурси в 2013 году межгосударственные отношения улучшились, укрепились военные и торговые связи. В 2014 году во время посещения Сиси Сочи, Путин обещал ускорить продажи оружия в Египет. "Активно развивается военно-техническое сотрудничество между двумя странами, в марте этого года подписан соответствующий протокол, ведется поставка наших вооружений Египту, сказал глава российского государства[6]. В ходе встречи так же обсуждалась зона свободной торговли с руководством России евразийского Таможенного союза, который также включает в себя Беларусь и Казахстан. Обе страны можно охарактеризовать как «близкие союзники». В области военно-технического партнерства Египет считается для Российской Федерации одним из первенствующих партнеров. В 2017 году российская федерация выиграла тендер на поставку Египту морской версии вертолетов Ка-52К на предназначавшиеся для ВМФ Российской Федерации вертолетоносцы вида «Мистраль». В октябре 2018 года руководитель Федеральной службы согласно военно-техническому сотрудничеству российская федерация информировал, что диалог согласно дооснащению «Мистралей» также поставке вертолетов во Египет пребывают в интенсивной фазе. Отечественные и египетские зенитчики в завершении октября - начале ноября 2019 года впервые проведут совместные учения ПВО «Стрела Дружбы-2019».

Египет играет ключевую роль во время кризиса в Персидском заливе в 19901991 г.г. Президент Мубарак помог собрать международную коалицию и развернуть 35000 египетских войск против Ирака, чтобы освободить Кувейт . Египетский контингент был один из крупнейших в коалиционных силах, наряду с США, Великобритании и Саудовской Аравии. В период после войны в Персидском заливе, Египет подписал дамасской декларацию с Сирией и государствами Персидского залива в целях укрепления безопасности в Персидском заливе. Египетский пример показывает, что активизация действий исламистов (насильственных и ненасильственных) является следствием кризисных явлений социальных, экономических, политических, культурных, региональных и международных[3].

Важнейший внешнеполитический приоритет Каира - ближневосточное урегулирование на основе соответствующих решений ООН и Арабской мирной инициативы. Каир выступает за налаживание международного сотрудничества в антитеррористической сфере. В области оружия массового уничтожения приоритет Египта - создание на Ближнем Востоке зоны, свободной от оружия массового уничтожения.

Арабская Республика Египет - член Лиги Арабских государств (штаб-квартира находится в Каире), Афросоюза, ОИС, Движения неприсоединения. Является партнером ОБСЕ, участвует в диалоге НАТО со странами Южного Средиземноморья. В июне 2004 года Египет стал ассоциированным членом Евросоюза. В июле 2016 года НАТО одобрило заявку Египта об учреждении Постпредства при альянсе (с 16 марта 2017 года его возглавляет по совместительству посол АРЕ в Бельгии).

$$
* * *
$$

1. История Египта: подробный справочник по истории: [перевод с английского] / Майкл Хааг. Москва : АСТ : Астрель, 2008. - ХIV, 255, [1] с. [C. 228]

2. Евтушенков В.П. После затишья: Россия и арабский мир на новом этапе. 9.06.2005 Журнал «Россия в глобальной политике». [Электронный ресурс]

3. Юрченко В.П. «Египет: проблемы национальной безопасности (1952-2002 гг.)» М., ИИИиБВ, 2003 [C. 26-27, 254]

4. Богатуров А.Д, Аверков В.В. История международных отношений. 1945-2008. - М.: Аспект Пресс, 2010. [C. 339]

5. Мировая политика и международные отношения. / [Ю.В. Косов и др.]; под ред. Ю. В. Косова СПб: Питер, 2012. [С. 188]

6. Выступление Путина В.В. на саммите «Большой восьмерки» в Сочи 2014 года 